\title{
高濃度 $\mathrm{Al}$ を含む $\mathrm{AM}$ 系合金の時効挙動
}

\section{Aging Behavior of AM System Alloys Containing a High Concentration of Al}

\author{
才川 清二*・南＼cjkstart和 希***寺山清志*・池野＼cjkstart進*** \\ Seiji SAIKAWA, Kazuki MINAMI, Kiyoshi TERAYAMA and Susumu IKENO
}

(Received November 13. 2014)

\begin{abstract}
The age hardening behavior and the change of the microstructure in Mg-Al system alloys containing 10 to $14 \% \mathrm{Al}$ were investigated by optical microscope, scanning electron microscope and micro-Vickers hardness measurement. When $\mathrm{Al}$ content was lowred 10 mass $\%, \beta$ phase is almost solid solution in the $\alpha$-Mg matrix by the solution treatment. On the other hand, $\mathrm{Al}$ content was overed $11 \mathrm{mass} \%$, the $\beta$ phase remained at grain boundary and cell-gaps in the $\alpha$-Mg matrix. As the solution treatment, the hardness was slightly increased with the increase of the $\mathrm{Al}$ concentration. When aging temperature is constant, the time to reach the maximum hardness is almost the same if differ in aluminum concentration. Therefore the difference of cellular precipitation sequence is not important for $\mathrm{Mg}-\mathrm{Al}$ system alloys with containing of high concentration $\mathrm{Al}$.
\end{abstract}

Key Words: Magnesium, Mg-Al Alloy, Aging Behavior, Microstructure, $\mathrm{Mg}_{17} \mathrm{Al}_{12}$

\section{1. 緒言}

$\mathrm{AM}$ 系マグネシウム合金は $\mathrm{Al}$ を含むことから、鋳造性お

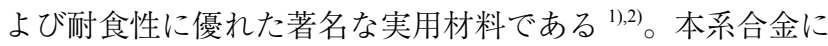
おける $\mathrm{Al}$ の最大固溶量は 12.7 mass\%（以下\%と略す）と 報告されており、また $\mathrm{Al}$ を $6 \%$ 以上含む合金において顕 著な時効硬化を示すことが報告されている ${ }^{3)}$ 。しかし、こ れまではAZ91 やAM60を中心とした研究が多く4)、さら に $\mathrm{Al}$ 濃度の高い固溶限付近および亜共晶組成における時効 組織に関する報告は少ない ${ }^{5), 6)}$

しかし、近年、溶質濃度の高い $\mathrm{Mg}-\mathrm{Al}$ 系合金が注目され 始めており、荒木ら ${ }^{7)}$ は、Mg-20\% Al 合金を用いて半溶融 成形加工を行って作製した試料の時効硬化特性を調べて報 告している。また、Magontec 社は Hymag2 合金を開発し、 ダイカスト用に実用している ${ }^{8)}$ 。Hymag2 合金は Alを約 8 $\%$ および Zn を約 $15 \%$ と多量に添加しており、従来のダイ カスト用 $\mathrm{Mg}-\mathrm{Al}-\mathrm{Zn}$ 系合金に比べて溶質濃度は非常に高い。 このことにより従来合金にはない優れた流動性が得られ、 また鋳造割れ等が生じにくい組成領域でもあることから、 製造されたダイカスト部品の品質が改善され、とりわけ外 観品質が向上している。従って複雑形状品、薄肉品および
外観意匠性が従来にも増して問われる部品に好適な新合金 と言え、今後の進展が期待されているが、こうした合金系 において溶質濃度が変化した場合の時効硬化挙動への影響 は、いまだ系統立てて研究されていない。

そこで本研究では、10～14\%の $\mathrm{Al}$ を含む $\mathrm{Mg}-\mathrm{Al}$ 系合 金について、光学顕微鏡および走査型電子顕微鏡を用いた 組織観察、ビッカース硬さ試験機を用いた硬さ測定により、 時効硬化挙動とミクロ組織の変化を調査した。Al 濃度の増 加に伴う凝固組織の変化や、溶体化処理および時効処理を 施した際のミクロ組織の変化について調べた結果について 報告する。

\section{2. 実験方法}

鋳造は我々の既報と同様な方法で行った ${ }^{3)}$ 。今回使用し た合金は、工業用純度の純 $\mathrm{Mg}(99.9 \%) 、$ 純 $\mathrm{Al}(99.99 \%) 、$ Mg-Mn 母合金を用いて総量が 400 gf となるように各材料 を切り出して作製した。溶湯の燃焼を防止することを目的 として $30 \mathrm{ppm}$ 相当の Be を含むように $\mathrm{Al}-2.5 \% \mathrm{Be}$ 母合金 を用いて添加した。合金の目標組成は $\mathrm{Mg}-\mathrm{X} \% \mathrm{Al}-0.3 \% \mathrm{Mn}$ とし、X を 10、11、12、13 および 14 として溶製した（以下、 AM100、AM110、AM120、AM130 およびAM140 と称す)。

*富山大学大学院 理工学教育部材料機能工学科（下 930-8555 富山県富山市五福 3190)

Nano and Functional Material Science Graduate School of Science and Engineering for Research, University of Toyama

(3190 Gohuku,Toyama, Toyama, 930-8555 Japan)

**大同特殊鋼侏 研究開発本部（

Daido Steel Co.,Ltd. (Daido, Minami, Nagoya, Aichi, 457-0811 Japan)

$* * *$ 北陸職業能力開発大学校 (T 937-0856 富山県魚津市川縁 1289-1)

Hokuriku Polytechnic Corporation (1289-1 Kawaberi, Uozu, Toyama, 937-0856 Japan) 
Table 1 Chemical compositions of specimens. (mass\%)

\begin{tabular}{|c|c|c|c|c|}
\hline & Al & Mn & Fe & Mg \\
\hline AM100 & 10.11 & 0.37 & 0.003 & Bal. \\
\hline AM110 & 10.51 & 0.37 & 0.004 & Bal. \\
\hline AM120 & 11.72 & 0.37 & 0.002 & Bal. \\
\hline AM130 & 13.14 & 0.42 & 0.007 & Bal. \\
\hline AM140 & 14.67 & 0.37 & 0.006 & Bal. \\
\hline
\end{tabular}

各合金の化学組成を Table 1 に示す。溶解は電気炉中で温 度を $1043 \mathrm{~K}$ として SUS430 製のるつぼを用いて行い、マグ ネシウムの燃焼を防ぐために溶湯表面に $\mathrm{CO}_{2}+\mathrm{SF}_{6}$ 混合ガ スを吹き付けながら行った。各材料を添加した後、溶湯表 面の酸化膜を取り除き、擋找を行い、鉄製の鋳型に鋳型温 度を $453 \mathrm{~K}$ 、溶湯温度を $953 \mathrm{~K}$ として重力鋳造した。鋳型 には $\mathrm{TiO}_{2}$ を塗型し、加熱乾燥処理後に注湯を行っている。 鋳物は鋳型温度が $473 \mathrm{~K}$ になったところで離型し、大気放 冷した。得られた鋳物は寸法が $30 \times 12 \times 100 \mathrm{~mm}$ の試料片 採取部と逆台形型の押湯部を持つ Y ブロック形状鋳物であ る。今回の実験に用いた試料は、試料片採取部と押湯部を 切り離した後、試料片採取部から寸法を $15 \times 12 \times 2 \mathrm{~mm}$ と して板状に切り出したものを用いた。

溶体化処理は電気炉を用いて、Ar ガス雾囲気中にて温 度を $708 \mathrm{~K}$ 、保持時間を $86.4 \mathrm{ks} \sim 691.2 \mathrm{ks}$ として加熱保持 し、その後強制空冷した。時効処理はオイルバスを用いて、 423、473 および $523 \mathrm{~K}$ の 3 水準で、時間を $2.7 \mathrm{ks} \sim 1382.4$ ksとして行った。

硬さ測定にはマイクロビッカース硬さ試験機を用い荷重 $0.1 \mathrm{kN}$ 压時間 $20 \mathrm{sec}$ の条件で測定した。本研究において は、時効処理による硬さ変化を正確に得るために、晶出相 を避けて母相のみの硬さの変化を測定した。組織は光学顕 微鏡㧍よび走査型電子顕微鏡（以下、SEM と称す）を用い て行った。晶出相の体積率の測定は、画像処理解析ソフト を用いて行った。合金の構成相の同定は、X 線回折装置を 用い、ターゲットは $\mathrm{Cu}-\mathrm{K} \alpha$ を使い $40 \mathrm{kV} 、 40 \mathrm{~mA}$ の条件で 測定を行った。

\section{3. 実験結果}

鋳造まま材の光学顕微鏡組織を Fig. 1 に示す。AM100 の写真から分かるように、いずれの合金においても白色の $\alpha-M g(\alpha)$ 相と、結晶粒界抢よび $\alpha$ 相の七ル間隙に凝固末期 に晶出したと思われる $\beta-\mathrm{Mg}_{17} \mathrm{Al}_{12}(\beta)$ 晶出相が観察された。 $\beta$ 晶出相は $\mathrm{Al}$ 濃度の増加に伴い、量が増えていくと同時に 晶出相自体も粗大化して、AM100 と比較してAM140では 結晶粒界を覆うようにして晶出していることが分かる。一

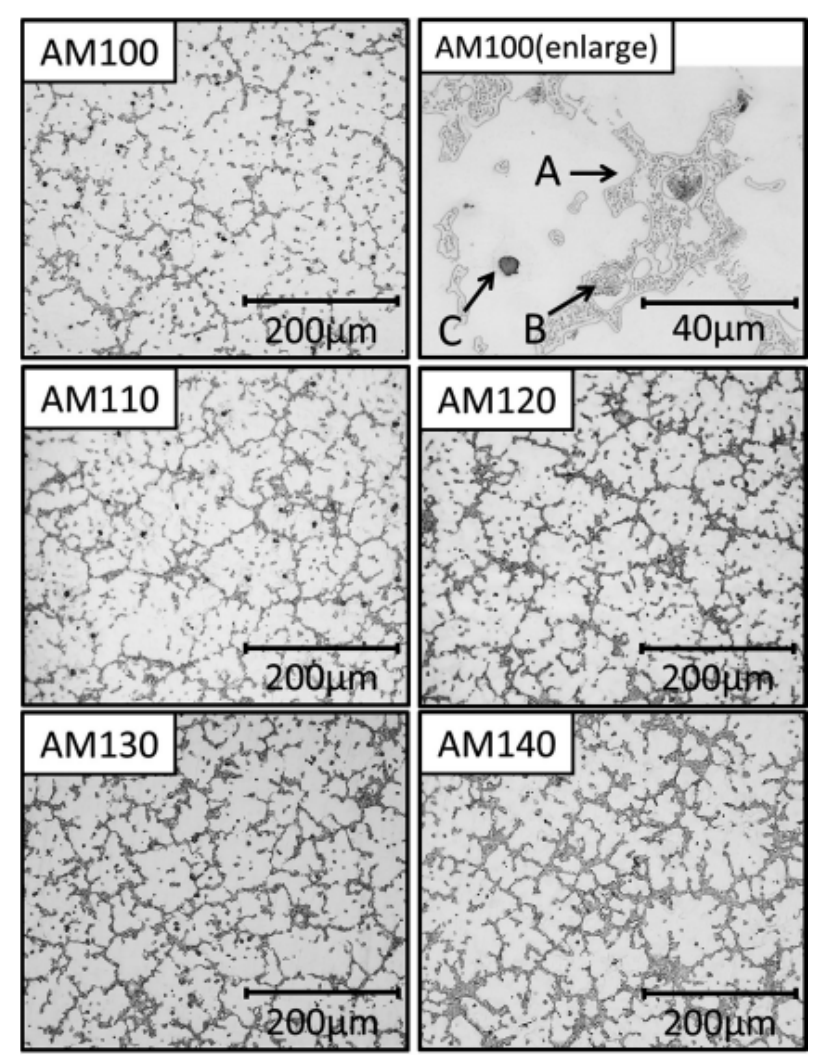

Fig.1 Microstructure of as-cast alloys.

方、AM100 を拡大してみると、図中に書き込んだように A では $\beta$ 晶出相が見られる。また晶出相の内部には $\alpha$ 相が点 在して扮り、部分的に分離した分離共晶となっていること が分かる。Bでは凝固した後にソルバス直下の温度域にて 晶出相近傍に析出した $\alpha$ 相と $\beta$ 相から成る層状の析出相が 見られる。Cでは黑色の Al-Mn 系金属間化合物と思われる 晶出相が見られる。

Fig. 2 は AM100 の SEM 像および分析結果である。

光学顕微鏡とは逆に、SEMによる二次電子像では黒色 の $\alpha$ 母相抢よび白色の $\beta$ 晶出相が見られる。面分析結果か ら明らかなように、 $\beta$ 晶出相では $\mathrm{Mg}$ と $\mathrm{Al}$ が検出されてい る。晶出相としては、 $\beta$ 相と思われる相が大部分であるが、 SEM の分析の結果からごく一部に Mn が粒状に見られる。 従って Mn 系の晶出物も存在している事が分かる。AM120 合金の結果に見られるごとく、これらの様相は $\mathrm{Al}$ 添加量が 増えても類似している。

Fig. 3 に鋳造時における $\beta$ 相の体積率を測定した結果を 示す。 $\mathrm{Al}$ 添加量が増えるに従って、晶出量が増えており、 $\mathrm{Al}$ 濃度が $14 \%$ と多くなると、晶出量が約 $30 \%$ と増加して いる事が分かる。本研究に用いた $\mathrm{Al}$ 濃度では、鋳造時に $10 \mathrm{vol} \%$ から $30 \mathrm{vol} \%$ という高体積率の $\beta$ 相が、晶出する事 が分かる。 
(a)

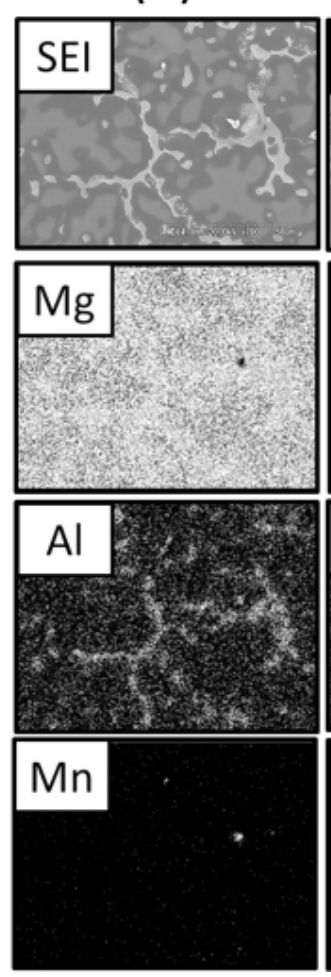

Fig. 2 SEM image of as-cast alloys and elemental mapping in (a) AM100 and (b) AM120 alloy.

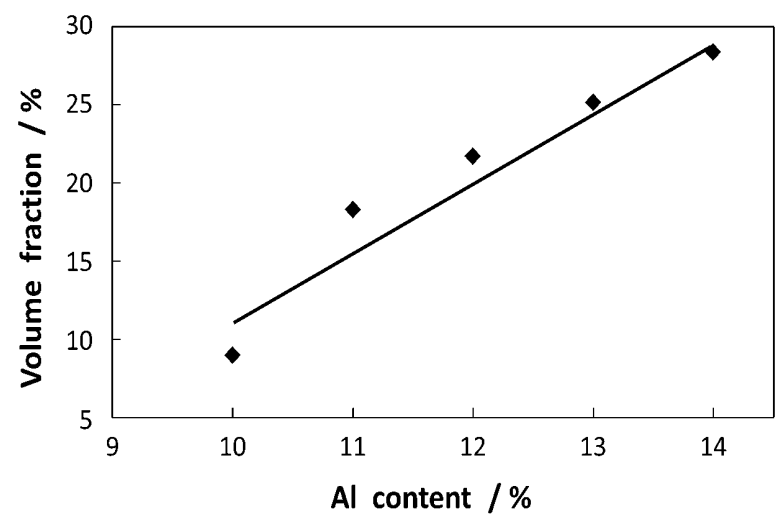

Fig. 3 Volume fraction of crystallized $\beta$ phase on as-cast alloys.

Fig. 4 は溶体化処理後の光顕組織であり、AM100 では結 晶粒界と疎らに存在する黒い点（Mn 系の晶出物と思われ る）が観察されるが、 $\beta$ 相は認められない事から、 $\mathrm{Al}$ 元素 が母相中に固溶している事が分かる。一方、AM110 以上の 試料では未固溶の $\beta$ 相が残存している。

Fig. 5 から分かるように、(a)の鋳造材において見られた $\beta$ 相中には凝固時に取り込まれたと思われる粒状の $\alpha$ 相が

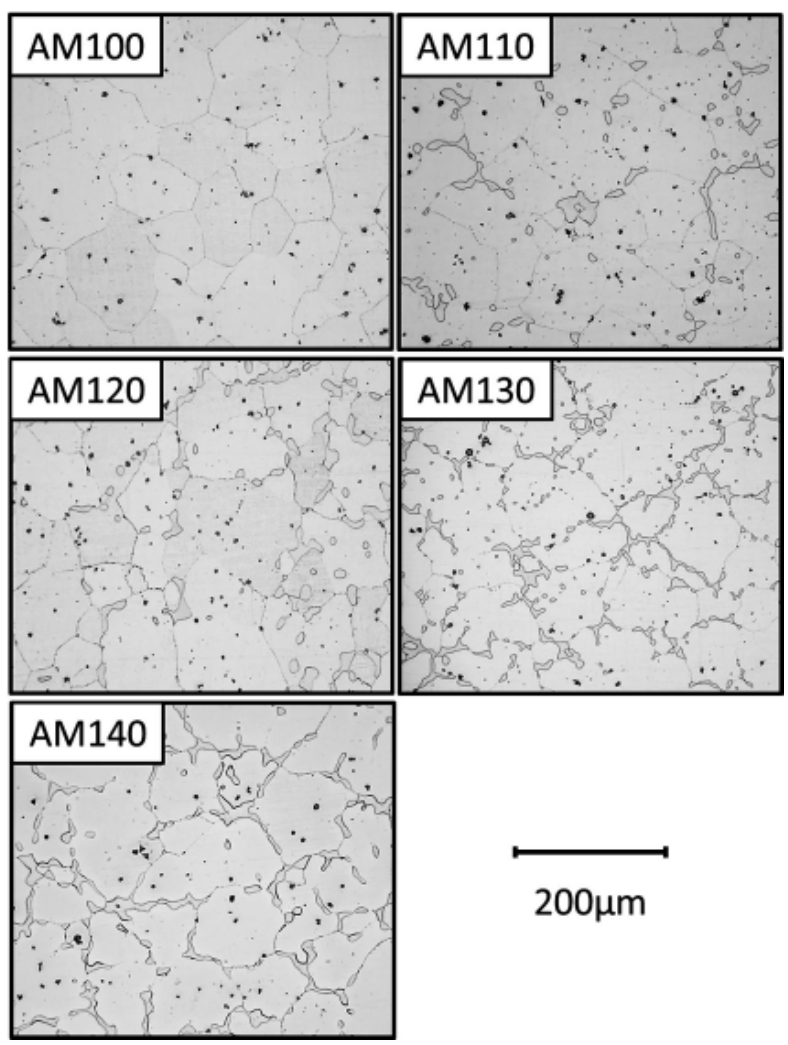

Fig. 4 Microstructure after solution treatment.

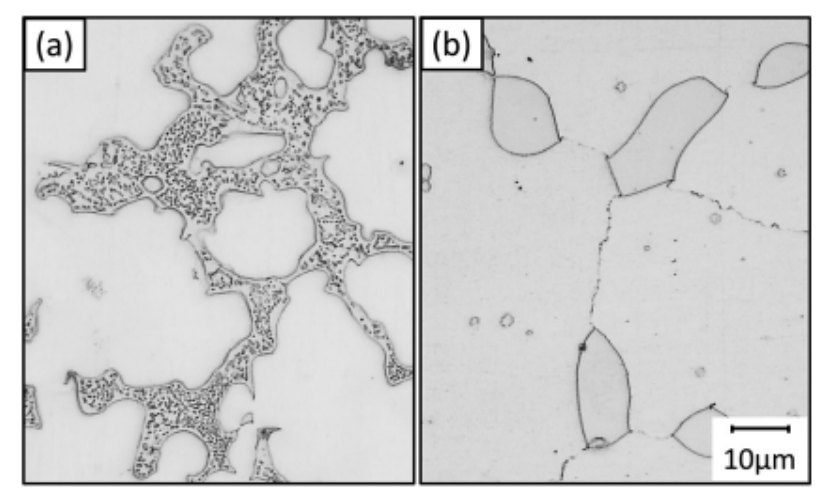

Fig. 5 Microstructure of AM120 alloy; (a) as-cast and (b) as-solution treated alloy.

見られるが、(b) の溶体化処理材では $\beta$ 相が凝集して大きく なると同時に $\beta$ 相内の $\alpha$ 相は消失しているようである。ま た、溶体化処理材の粗大化した $\beta$ 相はその形状が粒状に近 くなり、滑らかな縁に変化している。

$\mathrm{Al}$ 添加量を増加させた AM140では、Fig. 6(a)に見るよ うに、 $\beta$ 相の晶出量が更に多くなると共に、冷却中に析出 したと思われるラメラー状の析出物も観察されている。溶 


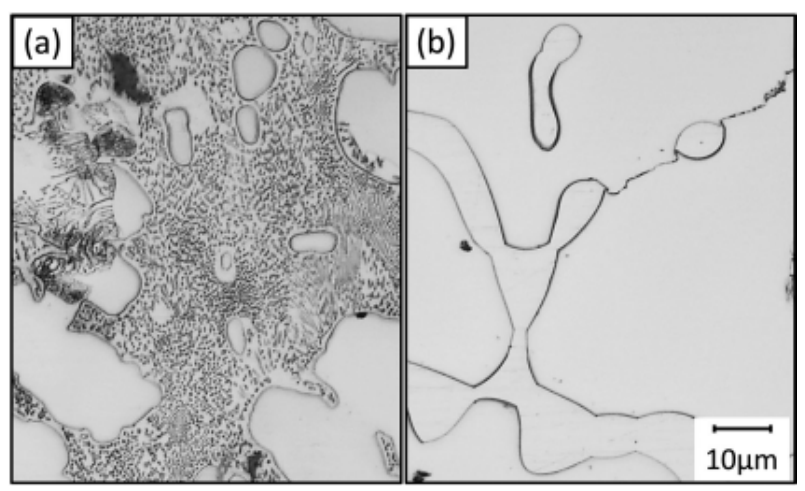

Fig. 6 Microstructure of AM140 alloy; (a) as-cast and (b) as-solution treated alloy.

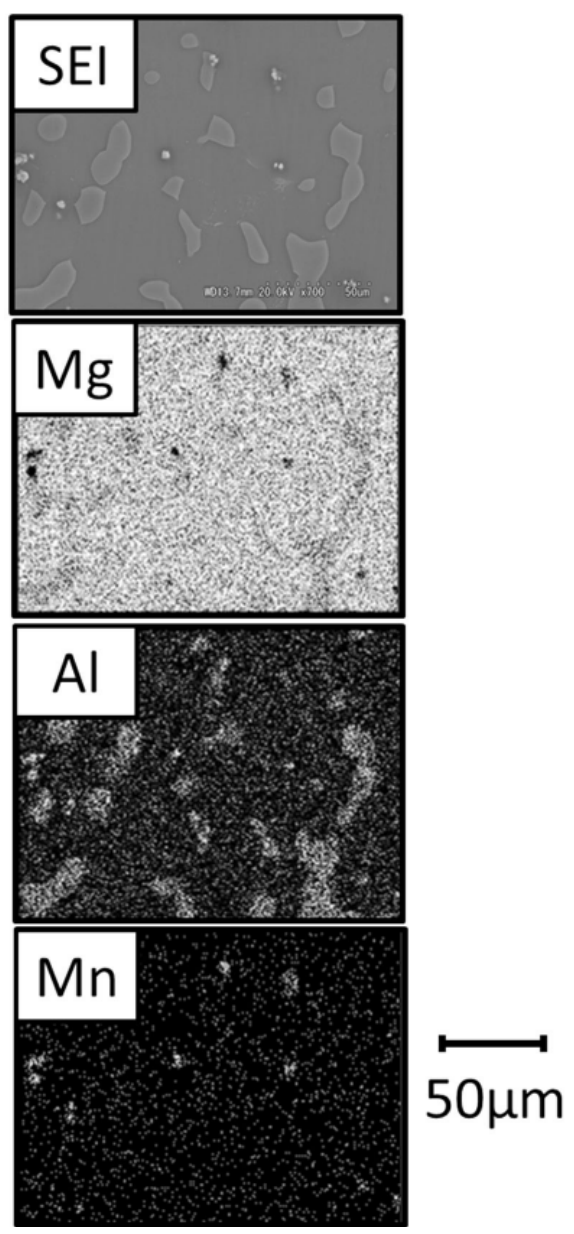

Fig. 7 SEM image of as-solution treated alloys and elemental mapping in AM120 alloy.

体化処理した (b) から分かるように、鋳造材で存在した $\beta$ 相中の微細な $\alpha$ 相およびラメラー状の析出物は溶体化処理 で消失している。溶体化処理で見られる $\beta$ 相はFig. 5 と同 様に粗大化して滑らかな縁を持つ形状に変化しており、結

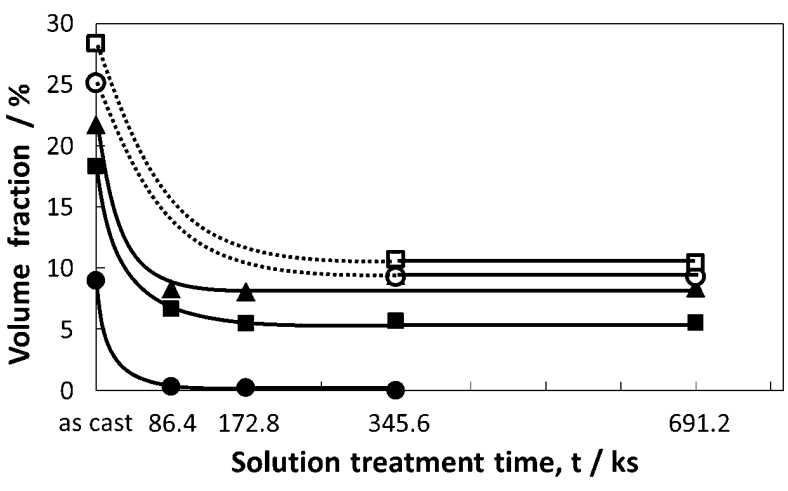

Fig. 8 Relationship of volume-fraction of crystallized $\beta$ phase time with solution treatment in $\operatorname{AM100}(\mathbf{O}), \operatorname{AM} 110(\boldsymbol{\square}), \operatorname{AM} 120(\mathbf{\Delta})$, $\operatorname{AM} 130(\bigcirc)$ and $\operatorname{AM} 140(\square)$ alloys.

晶粒界を覆う様な形状で分布している。

Fig. 7 の面分析結果から分かるように、白色晶出相では $\mathrm{Mg}$ と $\mathrm{Al}$ が検出されており、凝集して滑らかな縁になった 晶出物は $\beta$ 晶出相であるとわかる。また光顕組織で見えた 黒い粒子（SEM では白い粒子）からは Mn が検出されてい るので、Mn 系晶出物である事が分かる。こうした Mn 系 晶出物は鋳造時から溶体化処理してもその大きさ、分布等 に大きな相違は認められなかった。

Fig. 8 から分かるように、AM100では鋳造時に $10 \%$ 程 度存在していた $\beta$ 相が、24 時間で殆ど見られなくなり、96 時間保持でゼロとなっている。かなりの長時間保持が必 要であるが、AM100では溶体化処理が出来ている。一方、 AM110では 24 時間の保持で $\beta$ 相が $17 \%$ からほぼ $6 \%$ へと 急激に減少するが、ゼロにはならない。保持時間を 96 時間 と伸ばしても約 $5 \%$ 程度とほとんど变化が見られなく、溶 体化処理による $\mathrm{Al}$ の完全な固溶状態は得られない事がわ かる。AM120 と Al 添加量が増えると $\beta$ 相の残存量は多く なり、96 時間保持しても約 $8 \%$ 程度の $\beta$ 相が残存していた。 AM130では約 $9.5 \%$ の $\beta$ 相が残存しており、AM140では 約 $11 \%$ の $\beta$ 相が残存している。AM110 から AM120の間で は残存する $\beta$ 相の体積率はほぼ $3 \%$ と増加するが、AM120 から AM130、AM130 から AM140ではいずれもほぼ $1.5 \%$ と増加量は少なくなっていた。これらの結果から今回評価 した合金中では、最も $\mathrm{Al}$ 濃度の低い AM100においてのみ 溶体化処理を施すことによって $\beta$ 相のほぼ全てが拡散固溶 し、これにより $\alpha$ 単相のみの組織となることが明らかとなっ た。

各合金について溶体化処理を施した後に、423 K の温度 で時効処理を施した際の時効硬化曲線を Fig. 9 に示す。今 回使用した全ての合金において、時効時間の経過に伴い、 硬さの上昇が見られた。 $\mathrm{Al}$ 濃度の増加に伴い、最高硬さ が上昇する傾向が見られる。AM100 と AM110を比較する と最高硬さは大きく上昇していることが分かる。その後 
$\mathrm{AM} 110$ から AM130までは Al 濃度の増加に伴う、最高硬 さの上昇はわずかとなっている。AM140では AM130 と最 高硬さはほぼ変わらなかった。またAM100から AM120ま では、Al 濃度が高い合金ほど硬さの上昇が早い段階で見ら れており、Al濃度の増加に伴って最高硬さに達する時間 が短時間側に移行する傾向が見られた。しかし AM130 と AM140 では、AM120よりも硬さの上昇が遅く、長時間側 で最高硬さに達するという結果が得られた。

Fig. 10 は AM100を $423 \mathrm{~K}$ で時効した時の光学顕微鏡組 織であり、Fig. 10(a)に示すように時効初期においては溶 体化処理材と同様に $\alpha$ 母相のみが見られるが、時効時間の 経過に伴って結晶粒界から結晶粒内に向かってセルラー析 出が進行し、結晶粒内を覆うに従って硬さが上昇している。 Fig. 10(b) に示すように亜時効組織ではセルラー析出のみ が見られているが、Fig. 10(c)に示すように時効時間がさ らに経過すると試料全面が大量のセルラー析出と時効途中 から生成した粒内析出で覆われて、硬さがピークに到達し、

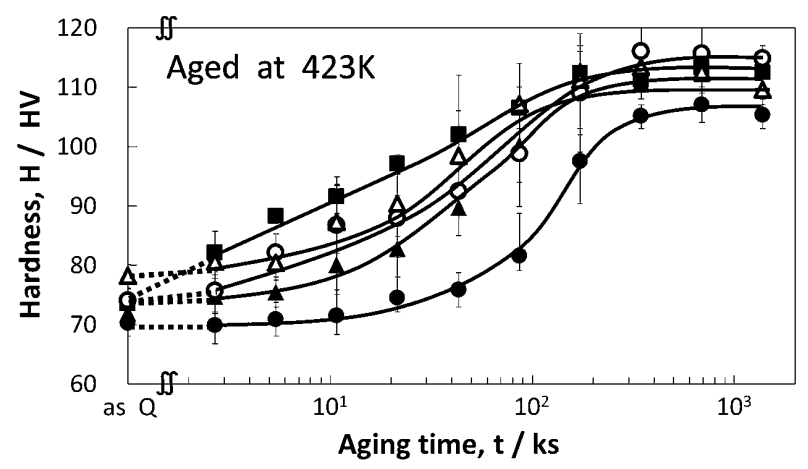

Fig. 9 Changes in micro-Vickers hardness of AM100 (О), AM110 (A), $\operatorname{AM} 120(\square), \operatorname{AM130}(\bigcirc)$ and AM140 $(\triangle)$ alloys aged at $423 \mathrm{~K}$.

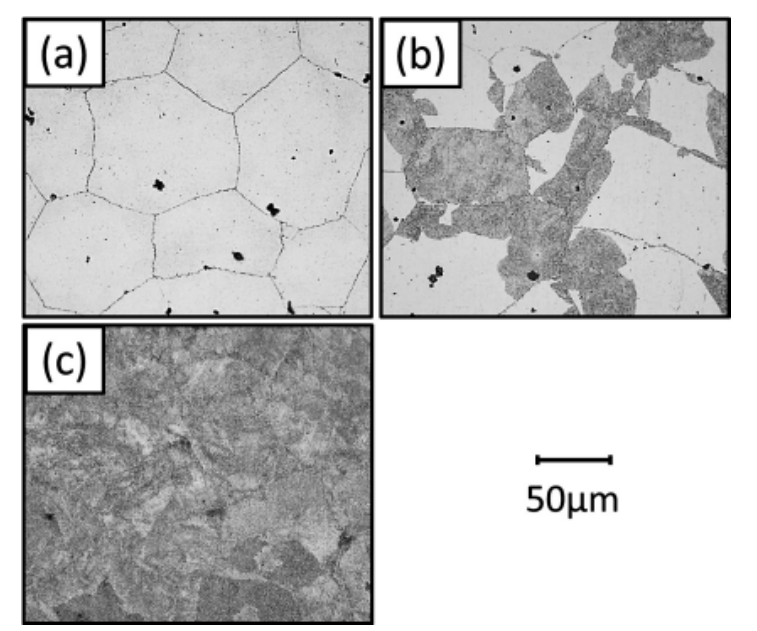

Fig. 10 Microstructure of AM100 alloy aged at $423 \mathrm{~K}$ for (a) 2.7, (b) 86.4 and (c) $1382.4 \mathrm{ks}$.

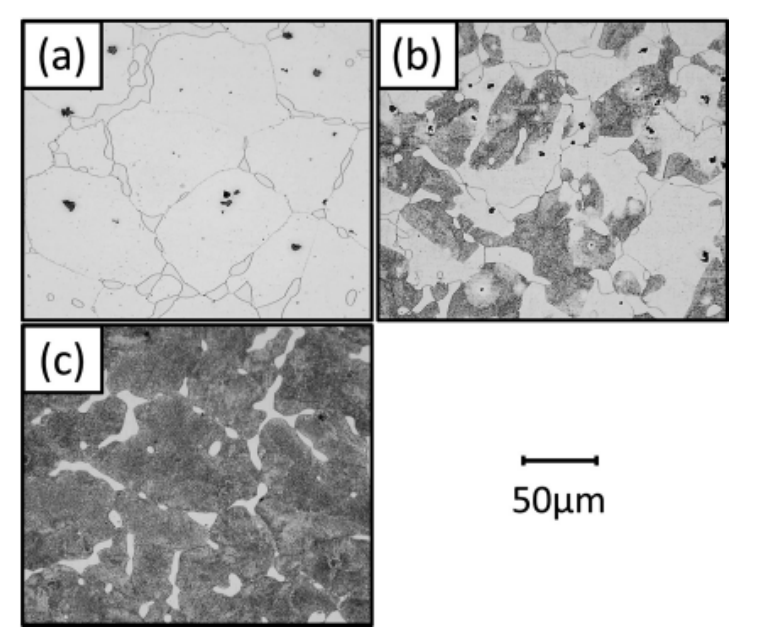

Fig. 11 Microstructure of AM110 alloy aged at $423 \mathrm{~K}$ for (a) 2.7, (b) 86.4 and (c) $1382.4 \mathrm{ks}$.

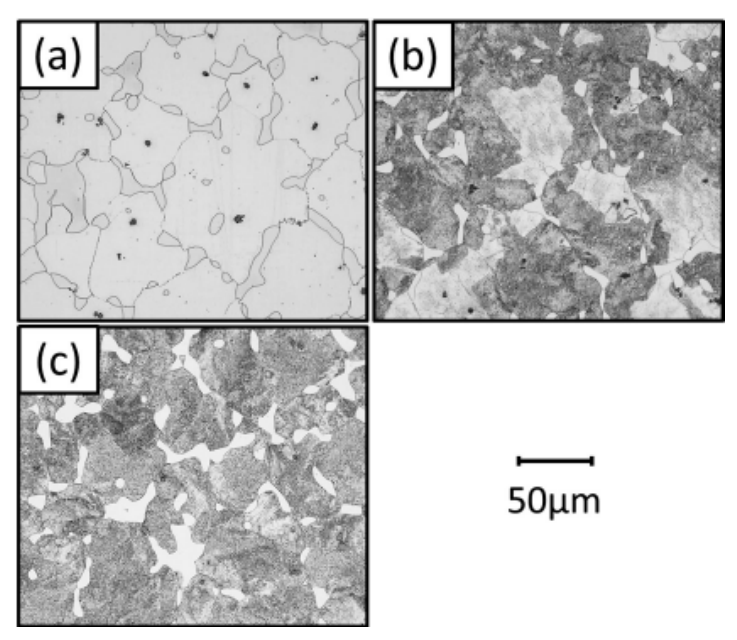

Fig. 12 Microstructure of AM120 alloy aged at $423 \mathrm{~K}$ for (a) 2.7, (b) 172.8 and (c) $1382.4 \mathrm{ks}$.

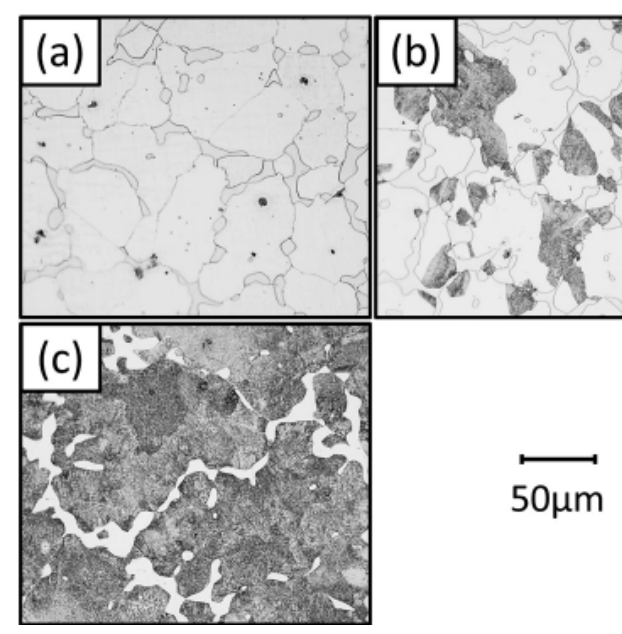

Fig. 13 Microstructure of AM130 alloy aged at $423 \mathrm{~K}$ for (a) 2.7, (b) 86.4 and (c) $1382.4 \mathrm{ks}$. 

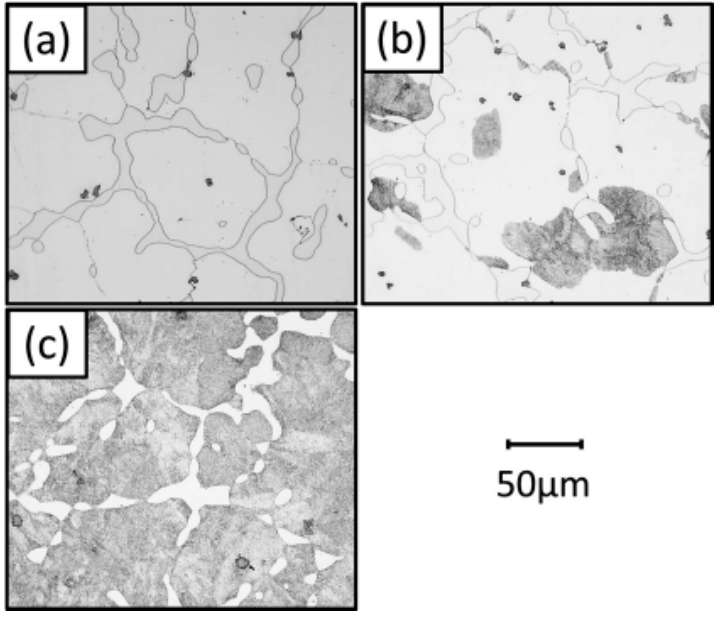

$50 \mu \mathrm{m}$

Fig. 14 Microstructure of AM140 alloy aged at $423 \mathrm{~K}$ for (a) 2.7, (b) 43.2 and (c) $1382.4 \mathrm{ks}$

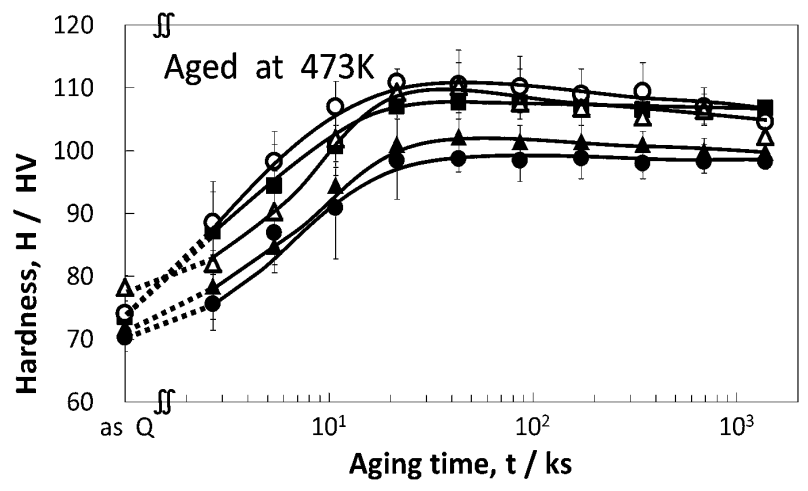

Fig. 15 Changes in micro-Vickers hardness of AM100 ( ), AM110 (A), $\operatorname{AM} 120(\square), \operatorname{AM} 130(\bigcirc)$ and AM140 $(\triangle)$ alloys aged at $473 \mathrm{~K}$.

その後の時効時間の経過では析出物の様相は殆ど変化しな い。硬さがピークに到達した後に殆ど変化しない事と析出 の様相が殆ど一定である事は良く対応していると思われ る。

Fig. 11、Fig. 12、Fig. 13 およびFig. 14 にはAM110、 AM120、AM130 および AM140を $423 \mathrm{~K}$ で時効した時の光 学顕微鏡組織をそれぞれ示す。AM110では溶体化処理を施 しても、結晶粒界に晶出相が残存した組織となっている。 AM110においても AM100 と同様に、時効初期においては 結晶粒界および結晶粒内に析出物は観察されていないが、 結晶粒界からセルラー析出が成長している。その後も同様 に、結晶粒全体がセルラー析出および粒内析出によって覆 われた組織となり、結晶粒界に残存する晶出相には時効前 後で変化は見られず、また晶出相が存在することによる析 出相への影響は見られなかった。AM120、AM130 および

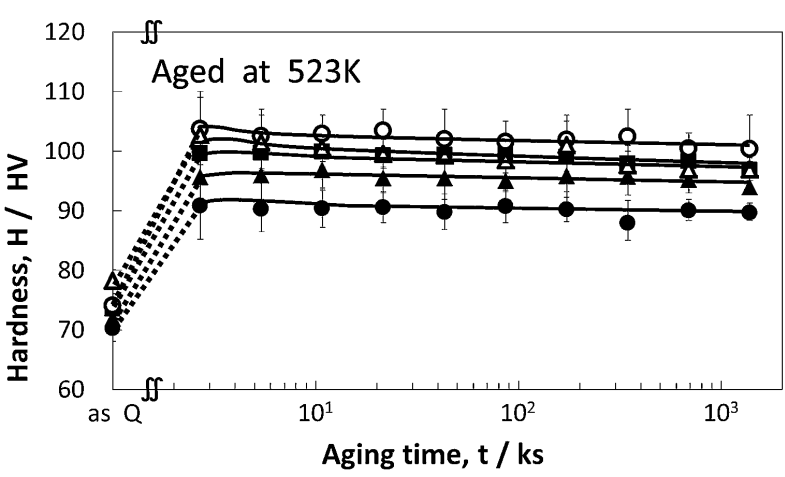

Fig. 16 Changes in micro-Vickers hardness of AM100 (O), AM110 (A), $\operatorname{AM} 120(\square), \operatorname{AM} 130(\bigcirc)$ and $\operatorname{AM} 140(\triangle)$ alloys aged at $523 \mathrm{~K}$.

AM140 を $423 \mathrm{~K}$ で時効した際のミクロ組織においても結晶 粒界に残存する晶出相の量が増加しても、時効時間の経過 に伴ってセルラー析出および粒内析出が成長し、結晶粒全 体が覆われた組織を呈している。Fig. 9 から分かるように、 ピーク時効の硬さは、AM100 が最も低く、AM110 以上の $\mathrm{Al}$ 濃度の試料においては、余り硬さの違いが見られない。

Fig. 15 に $473 \mathrm{~K}$ の温度で時効処理を施した際の AM 系マ グネシウム合金の時効硬化曲線を示す。時効温度を高めた $473 \mathrm{~K}$ 時効においても、423 K 時効と同様に時効時間の経過 に伴う硬さの上昇が見られており、AM140のみで $\mathrm{Al}$ 濃度 が増加したにも関わらず硬さの上昇に遅延が見られた。前 述の Fig. 8 でも示したように $\mathrm{Al}$ 含有量の最も高い AM140 においては、時効析出開始時（溶体化後）の未固溶の $\beta$ 晶 出相の残存量が約 $11 \%$ であり他の合金に比べて最も多い。 したがってそれらの粒界上に残存した晶出相が、時効初期 のセルラー析出の生成場所を最も減少させると思われ、こ のことが AM140における時効初期の硬さ上昇の遅延の要 因であるとも考えられるものの、詳細は今後の検討課題で ある。

$\mathrm{AM} 100$ から AM130 までは Al 濃度の増加に伴い、最高硬 さの上昇が見られているが、 $423 \mathrm{~K}$ 時効と同様に AM140の 最高硬さはAM130 とほぼ変わらない。全ての試料におい て時効時間の経過に伴って硬さが上昇し、最高硬さに到達 した後はゆるやかに硬さが減少し、次いで一定の值に漸近 するような傾向を示した。473 K 時効では、全ての合金が 時効初期から硬さの上昇を示しており、最高硬さに達する 時間に大きな違いは見られなかった。

Fig. 16 に $523 \mathrm{~K}$ の温度で時効処理を施した際の AM 系

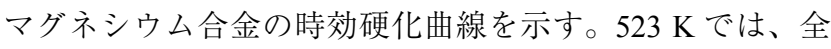
ての合金で時効初期から大きく硬さが上昇し、時効初期で 最高硬さに達している。AM100 から AM130 までは Al 濃度 の増加に伴い、最高硬さの上昇が見られているが、 $423 \mathrm{~K} 、$ $473 \mathrm{~K}$ 時効と同様に AM140 の最高硬さは AM130 とほぼ変 


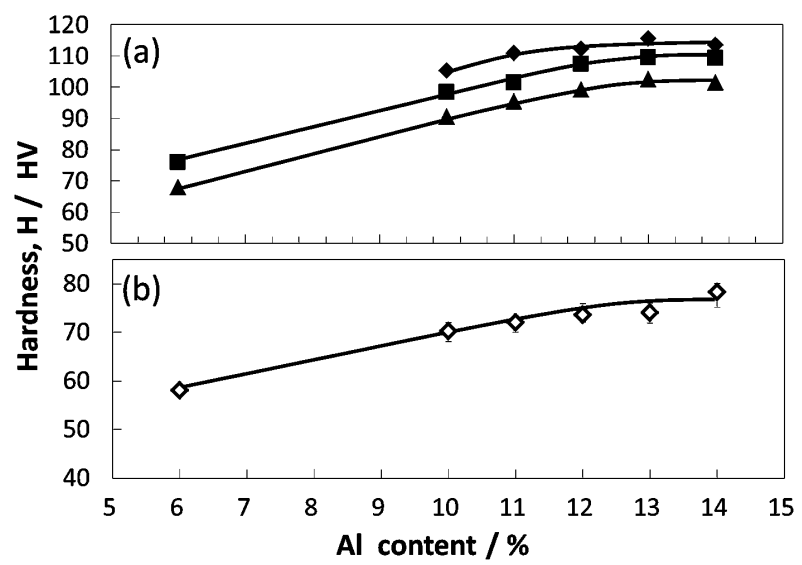

Fig. 17 Changes in micro-Vickers hardness of (a) peak aged specimen aged at $423 \mathrm{~K}(\boldsymbol{\bullet}), 473 \mathrm{~K}(\boldsymbol{\square})$ and $523 \mathrm{~K}(\boldsymbol{\Delta})$ and (b)as-solution treated specimen with $\mathrm{Al}$ content.

わらない。時効時間の経過に伴い、若干最高硬さから下がっ ているが、ほぼ一定の值を保っている。

\section{4. 考察}

$423 \mathrm{~K} 、 473 \mathrm{~K}$ および $523 \mathrm{~K}$ のピーク時効硬さ並びに溶体 化直後の硬さに関して、含有 $\mathrm{Al}$ 量との関係を求めた。この 結果を Fig. 17 に示す。なお、図中には過去に我々が報告 したAM60の結果も併記した ${ }^{9) 。}$

図から分かるように、溶体化処理直後では、Al 濃度の増 加と共に硬さが僅かに上昇している。一方、時効曲線のピー クの值は、ほぼ $10 \% \mathrm{Al}$ 辺りまでは $\mathrm{Al}$ 濃度の増加と共に急 激に上昇しているが、それを越えたあたりからほぼ一定と なっており、硬さの増加は認め難い。

状態図からは、 $\mathrm{Mg}$ 母相に固溶する $\mathrm{Al}$ 濃度は約 $13 \%$ と なっているが、本実験条件下では、Fig. 4 から明らかなよ うに、10\% $\mathrm{Al}$ までは溶体化処理によって固溶するようで あるが、それを越えると未固溶の $\beta$ 相が残存いるため、母 相中の $\mathrm{Al}$ 濃度はほぼ一定と推定される。即ち、時効処理に よって析出する割合は $10 \%$ 以上の $\mathrm{Al}$ 濃度ではほぼ同程度 であり、時効処理によって析出する量がほぼ同程度である 為に、それによる硬さの上昇量もほぼ一定となると考えれ ば、時効のピーク時の硬さが $10 \%$ 越えるあたりかほぼ一 定となる事の説明が出来るように思われる。

時効硬化曲線では、ピーク硬さが時効温度を固定すれば $10 \% \mathrm{Al}$ 以上でほぼ一定となったが、残存する $\beta$ 晶出物は

Fig. 4 から分かるように $\mathrm{Al}$ 濃度が増加するに従い増加して いる。溶体化処理直後の硬さ変化をみると、10\% $\mathrm{Al}$ から $14 \% \mathrm{Al}$ まで $3 \%$ のアルミ濃度の上昇に対して硬さが約 72 $\mathrm{Hv}$ から $75 \mathrm{Hv}$ 程度と $3 \mathrm{Hv}$ 程度の上昇しか見られない。残 存 $\beta$ 晶出物の硬さに対する影響は大変小さいので、時効に
よるピーク硬さには殆どその影響が出なかったものと推察 している。

Fig. 14(b) およびFig. 14(c) から明らかなように、Al濃 度が増して残存 $\beta$ 相が結晶粒界に存在している場合には、 $\beta$ 相を避けて、 $\beta$ 相が存在しない結晶粒界部分からセルラー 析出が生成して結晶粒内に進行するようである。このよう な生成場所の減少はその後のセルラー析出の成長に大きな 影響を与えると思われるが、セルラー析出と並行して生成 する粒内析出の影響で、試料全面を析出物が覆う為に要す る時間には残存 $\beta$ 相の影響は余り無い様である。Fig. 14(c) から分かるように、時効時間が経過すると、残存 $\beta$ 相の部 分を残して、試料全面を時効析出物が覆うようになる。の Fig. 9、15 および 16 の硬さ変化曲線を見るに、時効温度 が一定であれば、 $\mathrm{Al}$ 濃度が変化しても時効のピークに到達 する時間はほぼ同程度であり、七ルラー析出の析出過程の 相違は余り大きな影響を持たないと思われる。

\section{5. 結 言}

10 ～ $14 \%$ の $\mathrm{Al}$ を含む $\mathrm{Mg}-\mathrm{Al}$ 系合金について、鋳造ま ま材、溶体化処理材および時効処理材のミクロ組織観察と 硬さ測定により、時効硬化挙動およびミクロ組織の変化を 調査した。結果を以下に要約する。

(1)いずれの合金においても鋳造まま材のミクロ組織は、 白色の $\alpha-\mathrm{Mg}$ 母相、結晶粒界および $\alpha-\mathrm{Mg}$ 母相のセル間 隙に凝固末期に晶出したと考えられる $\beta-\mathrm{Mg}_{17} \mathrm{Al}_{12}$ 晶出相 および黑色の Al-Mn 系金属間化合物と思われる晶出相 が観察され、 $\mathrm{Al}$ 添加量が増えるに従って、 $\beta$ 相の粗大 化および晶出量の増加がみられた。

(2) 溶体化処理を施すと、11\%以上の $\mathrm{Al}$ 濃度では溶体化処 理による $\mathrm{Al}$ の完全な固溶状態は得られず、粒状に近い、 滑らかな縁を持つ形状の未固溶の $\beta$ 相が存在した。

(3) 溶体化処理を施した後、時効処理を施すと、時効時間 の経過に伴って結晶粒界から結晶粒内に向かってセル ラー析出が進行し、さらに時効時間が経過すると試料 全面が大量のセルラー析出と時効途中から生成した粒 内析出で覆われるが、 $\mathrm{Al}$ 濃度の増加に伴い残存 $\beta$ 相が 結晶粒界に存在しはじめると、 $\beta$ 相を避けて、 $\beta$ 相が存 在しない結晶粒界部分からセルラー析出が生成して、 結晶粒内に進行し、残存 $\beta$ 相の部分を残して、試料全 面を時効析出物が覆うようになった。

(4) 時効温度 $423 \mathrm{~K}$ および $473 \mathrm{~K}$ において、全ての試料で 時効時間の経過に伴って硬さが上昇し、時効温度 $523 \mathrm{~K}$ においては、全ての試料で時効初期から大きく硬さが 上昇したが、いずれも最高硬さに達した後は硬さの減 少はごく僅かであり一定の值に漸近する傾向を示した。

(5) 本系合金の時効硬化挙動において、硬さの上昇は残存 $\beta$ 晶出物の硬さに対する影響は大変小さく、時効時間の 経過に伴って析出するセルラー析出および粒内析出に 
起因しているが、 $\mathrm{Al}$ 濃度が変化しても時効のピークに 到達する時間はほぼ同程度であることから、セルラー 析出の析出過程の相違は余り大きな影響を持たないと 思われる。

\section{謝 辞}

本研究の一部に協力いただいた富山大学工学部素形制御 工学研究室の学生・重長泰弘君に感謝致します。

\section{参考文献}

1) 小島陽：表面技術、44-11 (1993) 866-872.

2) 福崎昌宏、田村洋介、河野紀雄：軽金属、55-9 (2005) 389-394.
3) 才川清二、渡辺克己、藤井要、土屋大樹、川畑常眞、池野進、 松田健二：軽金属、62-12 (2012) 473-478.

4) H.A. Patel, D.L. Chen, S.D. Bhole, K. Sadayappan: Materials and Design, 49 (2013) 456-464.

5) 田村洋介、柳澤毅、気田悠作、為広博、河野紀雄、Hiroshi SODA, Alexander McLean: 軽金属、57-10 (2007) 450-456.

6) 井上誠、岩井正雄、鎌土重晴、小島陽：軽金属、51-5 (2001) 285-289.

7) 荒木知美、加勇田徹、鎌土重陽、小島陽:軽金属、51-11 (2001) 608-613.

8) 才川清二、軽金属、60-11 (2010) 571-577.

9) 古井光明、高野浩史、池野進、山口友康、才川清二: 61-10 (2011) 532-537. 